\title{
Az FDM-rapyd prototyping technológia alkalmazási lehetőségeinek vizsgálata öntödei modellek gyártásánál
}

\author{
Gergely István
}

\section{Digest}

The paper presents results of the study related to the possible ways of improving FDM Rapyd Prototyping Tehnology in the process of manufacturing casting models.

In our experience workpieces were made of ABS plastics by using Fused Deposition Modeling technology. Finally prototyps were used as models in elaborating the refractary coat of casting workpieces.

\section{Az alkatrészek öntödei elôállítása gyorsfúzịós modellek segítségével.}

\section{Általánosságok}

Nagy méret- és formapontosságot igénylô alkatrészek öntödei gyártása esetén az öntvény formáját egy ideiglenes refraktáris héj adja meg, amelyet az öntvény megszilárdulása és kihûlése után szétvernek az alkatrész elôállítása érdekében.

Kis és közepes méretû, nagypontosságú alkatrészek esetén alkalmazzák e módszert, a modell alapanyagául pedig alacsony olvadáspontú gyanta-sztearin-paraffin keveréket használnak, amelyet a rárakódott külsô héj megszilárdulása és égetése (kalcinálása) során olvadás útján elfolyatnak. Ilyenformán méretpontos és finom felületû, választási heg nélküli öntvény-alkatrészeket nyerünk az öntés során.

E módszert használják forgácsolás útján nehezen megmunkálható, nagy precizitást igénylô, bonyolult konfigurációjú alkatrészek esetén is, amelyek nehezen vagy egyáltalán nem megmunkálhatóak hagyományos módszerekkel - szerszámgépeken.

Az alacsony olvadáspontú anyagból készült modell gyártásához fröccsöntôszerszám szükséges, ennek pontos elôállítása és megmunkálása viszont idô, energia és pénzigényes.

Ezt kiküszöbölendô kiiktatjuk a fröccsöntôszerszám elôállitását olyanformán, hogy öntödei modellünket nem a hagyományos fröccsöntôeljárással állitjuk elô, hanem ugyancsak alacsony olvadáspontú anyagot használva alapanyagul - Rapyd Prototyping eljárással hozzuk létre. 


\section{Az öntödei modellek elôállítása az FDM gyorsprototípusgyártó technológiával.}

Az FDM (Fused Deposition Modeling) módszer a munkadarabot ennek 3D-s testmodellje alapján, párhuzamos metszeteibôl lépcsôzetesen alakítja ki olvadt anyagszál lerakása során (1. ábra).

Rajz vagy vázlat alapján számítógépen elkészítettem a méretarányos 3D-s testmodellt, amelyet egymástól századmiliméter távolságra lévô, párhuzamos síkokkal metszettem, majd STL formátumú fájlként mentettem el. A 3D-s metszeteibôl álló modellt az FDM-1650 gép QuickSlice nevû szoftja dolgozza fel, amely alapján a gép metszeteibôl építi fel az alkatrészt (2. ábra).
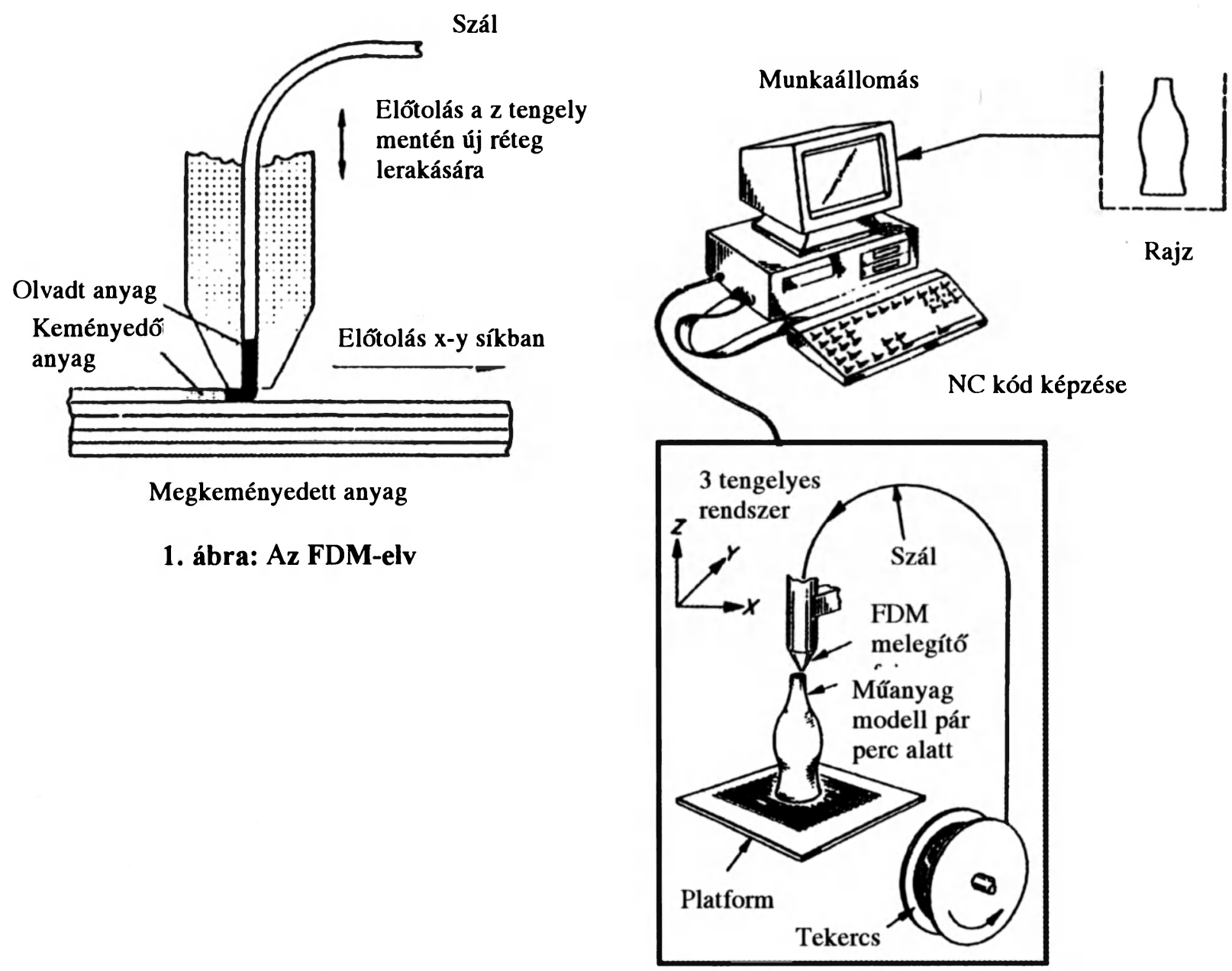

2. ábra: Az FDM rendszer felépítése

A. Vizsgálatunk tárgyát a hátizsákok vállpántjának rugalmas mûanyagcsatja képezte.

B. Az FDM-1650 Rapyd Prototyping rendszer alkotóelemei:

- QuickSlice Software

- UNIX vagy kompatibilis (HP, SUN) munkaállomás - a mi esetünkben Pentium 64 MRAM, Windows NT

- Testmodellezô rendszer: CATIA, Pro/ENGINEER - a mi esetünkben AutoCAD R13 
- FDM-1650 berendezés

C. Az FDM-rendszerrel elôállitott alkatrészek esetén használt technológiai paraméterek:

- felhasznált anyag:

ABS-szál tekercs fomrájában

- olvadáspont:

$270^{\circ} \mathrm{C}$

- elôállítási idô:

1,7 óra

- lerakott olvadt-anyag száljának hossza:

$2,2 \mathrm{~m}$

- lerakott olvadt-anyag térfogata:

$5,5 \mathrm{~cm}^{3}$

- lerakott olvadt-anyag költsége:

$0,3 \$ / g$

- a gép mûködési költsége:

5 \$/óra.

\section{Az öntvények elôállítása. Vizsgálat és kiértékelés.}

Az FDM módszer alapján a fenti paraméterekkel elôállított modellt felhasználtam az öntödei forma-héj létrehozására a következô lépéseket követve:

- az RP-modellek ún. „fürtökbe” való rendezése és felragasztása a tartórúdra gyanta segitségével zsírtalanitás fürdôben (15-20 perc)

- a hôálló héj réteges létrehozása a modell többszöri és egymásutáni festékbe, homokba majd fixáló fürdôbe való helyezésével elôszáritás levegôn, 20-30 perc

- a modell olvadás útján történô eltávolítása - elfolyatás fürdôben $\left(90^{\circ} \mathrm{C}\right)$

- a megkeményedett héj végsô száritása kemencében (130-150 $\left.{ }^{\circ} \mathrm{C}\right)$ és a maradék modell-anyag elégetése

- a héjak öntô-edényekbe és homokba való „pakolása”

- a héjak kalcinálása $\left(900^{\circ} \mathrm{C}\right.$-on hevités 16 órán keresztül)

- öntés

- héjak szétverése

- öntvény-alkatrészek felületének tisztitása (csiszolás, kémiai maratás)

Vizsgálat és kiértékelés:

A fent leírt módszer alapján elôállított öntvények tanulmányozása alapján a következôket állapítottam meg:

1. Az FDM-módszerrel elóállitott prototípus alapanyagául $A B S-$ t használtunk, melynek $270^{\circ} \mathrm{C}$ az olvadáspontja. Az UNIREA gyárban használt modellek alapanyaga $80^{\circ} \mathrm{C}$ olvadáspontú gyanta volt, ennek következtében az ABS prototipus olvadás-folyatás útján történô eltóvolitása a héjakból nem történhetett meg sem a gyanta olvadásával együtt a $80^{\circ} \mathrm{C}$-os fürdôben, sem pedig a héj kemencében történô száritása során $\left(130-150^{\circ} \mathrm{C}\right)$.

Így a héjakban maradt prototípust csak a késôbbiekben tudtuk eltávolítani a kalcinálás során $\left(800-900^{\circ} \mathrm{C}\right)$, amikor is elégett, hátrahagyva a héj alján az égéstermékeket. 
Következtetés: $A$ késôbbiekben alacsonyabb olvadáspontú anyagot kell használnunk a prototípus alapanyagául, ugyanakkor növelnünk kell a héjak elôszáritási hôfokát, betartva a technológiai határokat. 2. Kalcinálás végett homokkal töltött öntô-edényekbe pakolják a fürtökbe rendezett héjakat, öntési tölcsérrel felfele. Így az ABS - elérve olvadáspontját - nem tudi kifolyni a héjakból, majd a hômérséklet növekedésével benne ég, hátrahagyva az égéstermékeket.

Következtetés: Szükség lenne olyan technológiai megoldások tanulmányozására és alkalmazására, amely lehetôvé tenné az olvadt ABS elfolyatását a héjak kalcinálása során.

3. A fenti okok miatt az öntvények alsó felülete érdes és hibás lett a héjban rekedt égéstermékek jelenléte miatt.

Következtetés: A jövôben optimálni kellene az FDM módszerrel elóállitott prototípusok alakját és méretét olyan formán, hogy az esetleges égéstermékek a modell egy nemfunkcionális, auxiliáris részében gyûljenek össze, amelyet darabolás vagy csíszolás útján eltávolithatnak a késôbbiekben.

Végsô lépésként, de nem utolsósorban, szükséges és elengedethetetlen egy összehasonlitó költségelemzés, amely eldöntheti, hogy gazdaságos-e vagy sem az öntvény-modellek gyártása esetén a FDM RPtechnológia alkalmazása.

\section{Irodalomjegyzék:}

1. XXX Fused Deposition Modeling. Stratasys Inc. Manual de operare al maşinii FDM-1650

2.Bâlc Nicolae: Fabricarea flexibilã asistatã de calculator. Note de curs. Facultatea TCM, 1997.

3.Simion Buzilã: Procedee speciale de formare. Editura Tehnicã ši Pedagogicã, Bucureşti, 1978.

Gergely István / okl. gépészmérnök

S.C. Kopiernicus Birotica SRL / Jókai (Napoca) utca 2-4

Telefon/Fax: (0040)-64-191486

Mobil: (0040)-092-354129 